\title{
Meal timing, fasting and glucocorticoids interplay in serum leptin concentrations and diurnal profile
}

Amira Elimam and Claude Marcus

Department of Paediatrics, Endocrine Research Unit, Huddinge University Hospital, Karolinska Institute, S-141 86 Stockholm, Sweden

(Correspondence should be addressed to A Elimam; Email: Amira.Elimam@klinvet.ki.se)

\begin{abstract}
Background: In a previous study, we reported a 4-fold increase in serum leptin following total parenteral nutrition given after surgery. We hypothesised that the perioperative fasting and stress contributed to this, possibly mediated by increased serum insulin and cortisol.

Objective: To test the hypothesis that fasting, in combination with glucocorticoids, sensitises the leptin response to subsequent energy intake.

Design: Healthy volunteers were randomised into two groups, one group received dexamethasone (DEX), $0.1 \mathrm{mg}$ twice daily for 3 days, while the other group served as a control. Each group was then subdivided into two feeding protocols. Protocol 1, where a standard meal was given at 0, 24, 36 and $48 \mathrm{~h}$ and protocol 2 where the same meal was given at 0 and $48 \mathrm{~h}$. Blood samples were drawn before, as well as every other hour during the study period for determination of serum leptin, insulin, glucose and cortisol concentrations.

Results: In all groups serum leptin increased significantly following each meal $(P<0.01)$. The rise in serum leptin in response to the standard meal was higher when the meal was taken in the evening $(P<0.001)$ or following longer duration of fasting $(P<0.02)$. In those fasting for $48 \mathrm{~h}$, leptin decreased by $60 \%$ and showed no diurnal variation. DEX intake increased leptin concentrations in those fasting for short periods $(P<0.02)$ but not for $48 \mathrm{~h}$.

Conclusions: Long durations of fasting sensitise the response of leptin to subsequent energy intake and abolish the DEX-induced upregulation of leptin. Meal timing is an important factor determining the leptin diurnal rhythm, but other factors must contribute since the leptin response to a standard meal taken in the evening was greater than to the same meal taken in the morning.
\end{abstract}

European Journal of Endocrinology 147 181-188

\section{Introduction}

Leptin is a protein hormone predominantly secreted from adipose tissue. It is believed to be involved in the regulation of energy intake and expenditure (1-3). The blood concentrations of leptin correlate with measures of body fat stores (4-6), but other factors must contribute to the regulation of leptin as serum concentrations vary greatly for a given body fat content (7). Leptin is regulated by numerous endocrine factors (8-10). In most studies glucocorticoids, in pharmacological doses or within the physiological range, upregulate leptin concentrations (11-13). In humans, insulin upregulates leptin concentrations but whether this is a direct effect or secondary to trophic effects on the adipocyte is controversial (14-19).

Circulating leptin has a diurnal profile with a nocturnal peak that is not acutely altered by food intake or changes in insulin and glucose concentrations in man (20). The underlying mechanism is not fully understood, but leptin rhythm seems to be more associated with meal timing than to the circadian clock (21). In addition, binge eating is reported to affect the diurnal leptin profile, also suggesting that the timing of energy intake is an important determinant of the diurnal leptin rhythm (22).

In rodents, feeding upregulates while fasting downregulates leptin within $3 \mathrm{~h}$ (23). In man, serum leptin concentrations are affected by longer periods of fasting and overfeeding, and the acute effects observed in rodents have not been demonstrated $(24,25)$. Starvation might sensitise the response of leptin secretion to subsequent energy intake. Refeeding or glucose infusion after a prolonged period of fasting increases serum leptin to basal concentrations within $24 \mathrm{~h}$ $(26,27)$.

In a previous study we found that post-operative total parenteral nutrition (TPN) induced a 4-fold rise

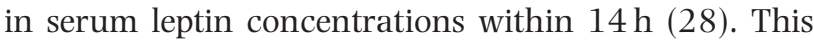
finding suggests that in man, as in rodents, nutrients 
acutely regulate leptin, possibly through induction of insulin. We hypothesised that the preoperative fast and surgical stress had sensitised the adipose tissue to the effect of nutrients, but the mechanism is still unclear. This study was designed to: (i) test the hypothesis that fasting sensitises the leptin response to subsequent energy intake; (ii) investigate if a low dose of glucocorticoid will affect the response of leptin to fasting or food intake; and (iii) study the effect of different meal timing on the leptin diurnal rhythm.

\section{Subjects and methods}

\section{Subjects and experimental protocol}

Thirteen healthy volunteers participated in four different protocols. Some of them participated in more than one protocol, so that in each protocol there were six or seven volunteers (Table 1). They had no known disease, and took no medication. The study was performed in four steps, in each step six or seven subjects were randomised in one of the four protocols. We have previously reported that exogenous glucocorticoids may affect metabolism for 1-2 months (29); therefore, the different studies were separated by a minimum of 2 months and a maximum of 3 months. All the volunteers gave their informed consent and the protocol was approved by the local Ethics Committee of the Karolinska Institute.

All the volunteers had normal feeding habits, i.e. they eat three meals and two snacks per day. There were no special instructions on the exact calorie intake or distribution during the day in the days preceding the experiment. They were asked to abstain from alcohol 3 days before the experiment, and not to eat or drink anything other than water after $2100 \mathrm{~h}$ the evening before the experiment. The groups taking dexamethasone (DEX) took the first dose at that time, and continued for the rest of the experiment 12-hourly, i.e. at 0900 and $2100 \mathrm{~h}$.

On day 1 the subjects reported to the laboratory at $0700 \mathrm{~h}$, where venous catheters were secured. The basal blood sample was taken at $0800 \mathrm{~h}$ and a standard meal was served at $0830 \mathrm{~h}$. They were allowed $30 \mathrm{~min}$

Table 1 Characteristics of the healthy volunteers participating in each protocol. Protocols: 1 , meals at $0,24,36$ and $48 \mathrm{~h} ; 2$, meals at $0,24,36$ and $48 \mathrm{~h}$ plus DEX; 3 , meals at 0 and $48 \mathrm{~h} ; 4$, meals at 0 and $48 \mathrm{~h}$ plus DEX. Values in parentheses are S.D.

\begin{tabular}{|c|c|c|c|c|}
\hline & \multicolumn{4}{|c|}{ Protocol } \\
\hline & 1 & 2 & 3 & 4 \\
\hline No. & 6 & 6 & 6 & 7 \\
\hline Sex (F/M) & $5 / 1$ & $3 / 3$ & $2 / 4$ & $3 / 4$ \\
\hline Weight (kg) & $65.8(11.2)$ & $81.6(13.8)$ & 78.5 (13.2) & $74.0(15.2)$ \\
\hline Height $(\mathrm{cm})$ & $166.6(6.3)$ & $178.8(13.5)$ & $180.7(9.0)$ & $173.3(7.9)$ \\
\hline Body mass index & 23.7 (3.2) & $25.5(2.5)$ & $23.9(2.4)$ & 24.5 (3.2) \\
\hline
\end{tabular}

to consume their meal, after which only water was allowed. Samples were taken every other hour till $1800 \mathrm{~h}$ and then the subjects were allowed to go home and come back at $0800 \mathrm{~h}$ next morning where blood samples were taken every other hour until the end of the experiment. During these 3 days the volunteers maintained low physical load indoor daily activities.

The four protocol groups were:

Protocol 1: intermittent feeding without DEX Following an overnight fast, a standard meal was taken at zero time (i.e. $0830 \mathrm{~h}$ on day 1), 24, 36 and $48 \mathrm{~h}$ later (Fig. 1).

Protocol 2: intermittent feeding with DEX Same as protocol 1, but the volunteers took $0.1 \mathrm{mg}$ DEX twice daily starting the night before the experiment and continuing for the duration of the experiment.

Protocol 3: fasting without DEX Following an overnight fast, a standard meal was taken at $0830 \mathrm{~h}$, thereafter only water was allowed. After a $48 \mathrm{~h}$ fast, the same meal was taken again (Fig. 1).

Protocol 4: fasting with DEX Same as protocol 3, but the volunteers took DEX, $0.1 \mathrm{mg}$, twice daily (0900 and $2100 \mathrm{~h})$ starting the night before the experiment and continuing for the duration of the experiment.

All groups were restrained on day 1 , with only $1000-1200 \mathrm{kcal}$ intake, to standardise between the groups, i.e. as a washout day as there were no specific instructions on the exact calorie intake before the experiment.

\section{The DEX dose}

The DEX dose of $0.2 \mathrm{mg} /$ day corresponds to approximately $40 \%$ of a normal substitution dose (30). We have used this dose in a previous study (13), where in young healthy men, it increased serum leptin by $50 \%$ within 2 weeks.

\section{Contents of the standard meal}

The meal was calculated as $50 \%$ of the total energy given per day in TPN in our previous study (28), i.e. $16 \mathrm{kcal} / \mathrm{kg}$ body weight, and consisted of $55 \%$ carbohydrate, $30 \%$ fat and $15 \%$ protein.

\section{Hormone measurements}

Blood samples were drawn for determination of serum leptin, insulin, glucose and cortisol. Serum leptin concentrations were determined by RIA (Linco Research Inc., St Charles, MO, USA). All samples were within the linear detection range, i.e. $0.5-100 \mathrm{ng} / \mathrm{ml}$, and analysed in duplicate. The intra-assay coefficient of variance was $6.8 \%$ at the low leptin concentration $(2.4 \mathrm{ng} / \mathrm{ml})$ and $3.5 \%$ at the high leptin concentration $(14.6 \mathrm{ng} / \mathrm{ml})$. Serum glucose was determined with an enzymatic hexokinase method (Gluco-quant; Roche 


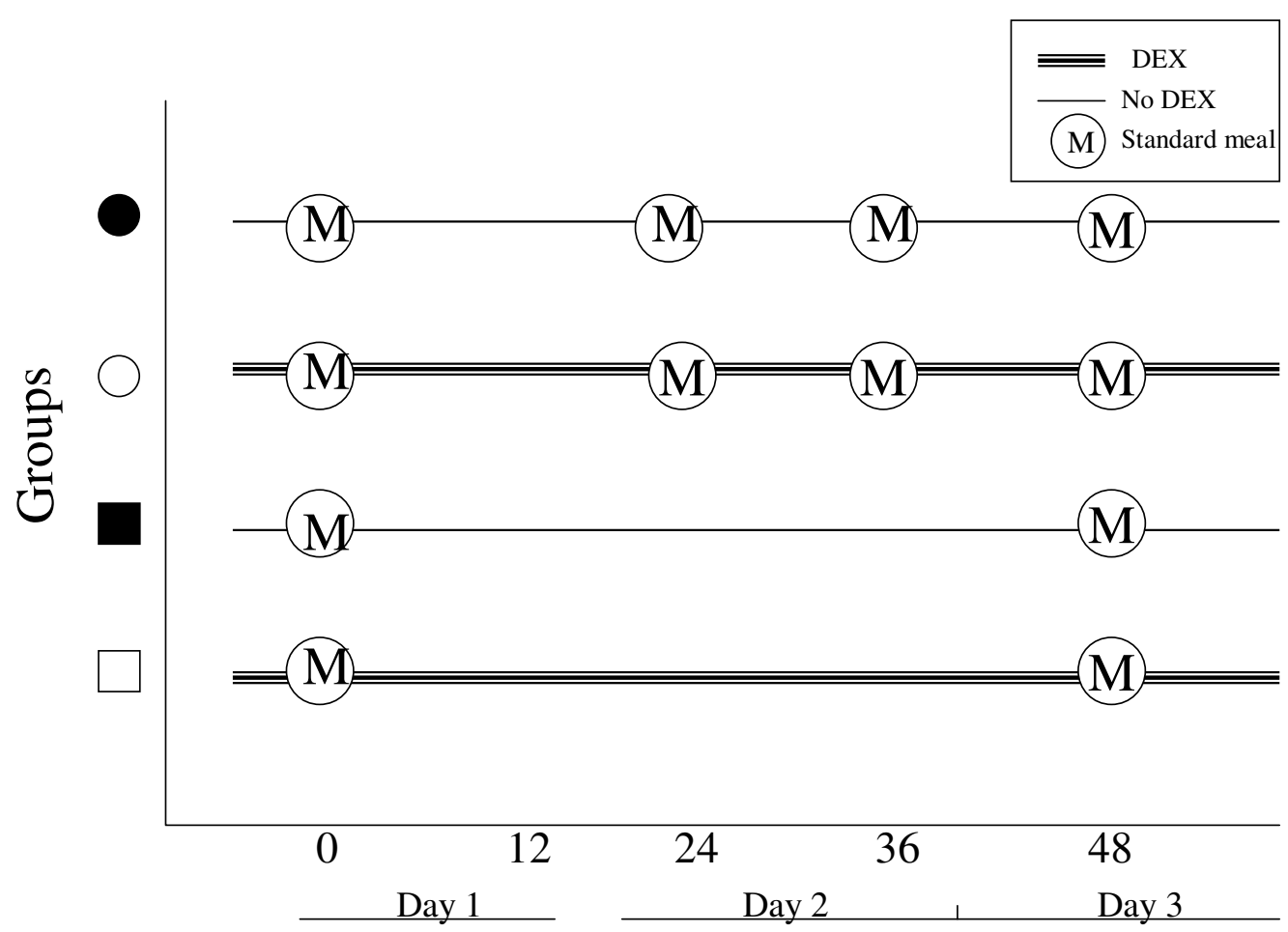

Time

Figure 1 Schematic presentation of the study protocol. Symbols denoting the different groups are: $\bullet$ eating intermittently; $\bigcirc$ eating intermittently and taking DEX; $\square$ fasting; $\square$ fasting and taking DEX.

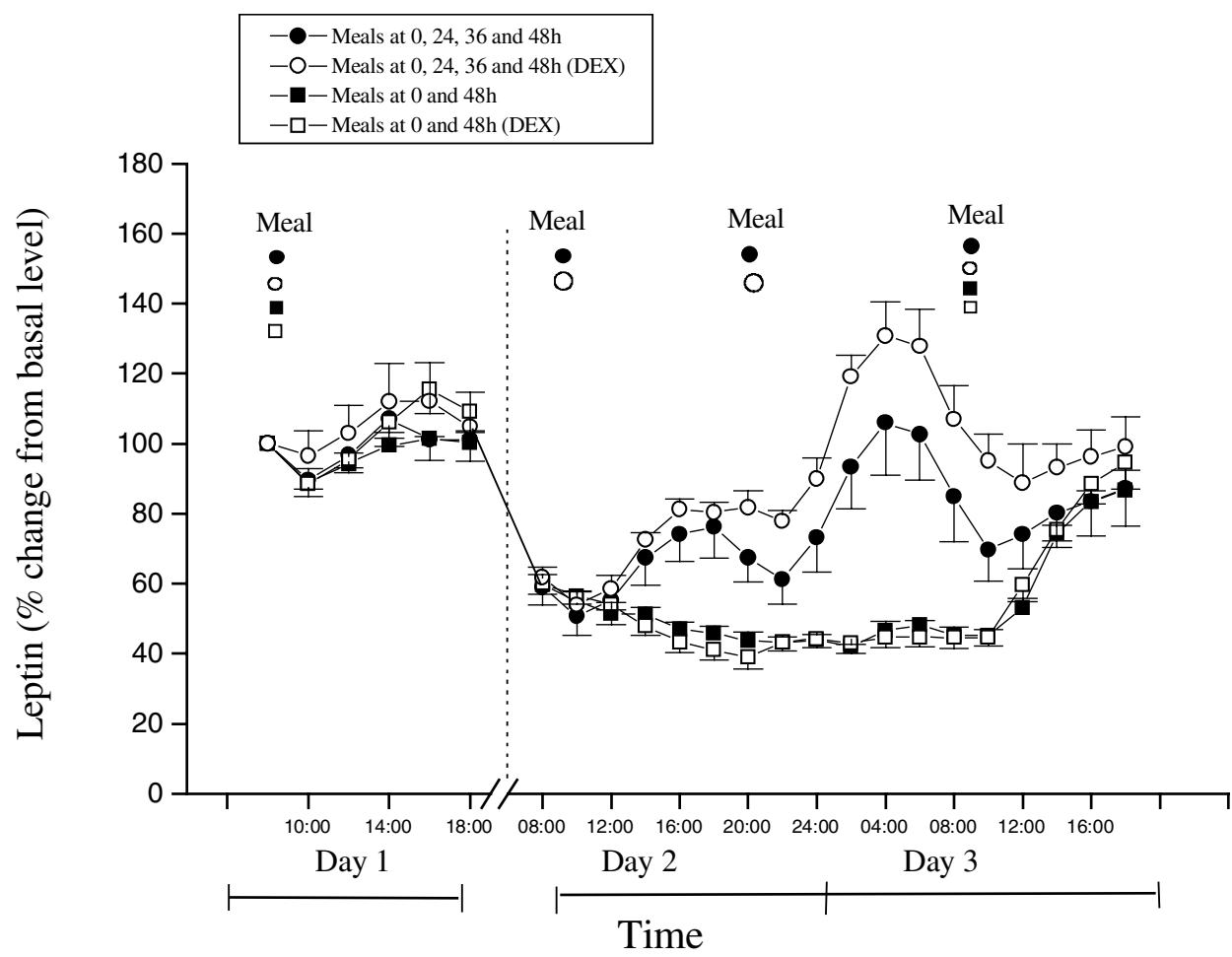

Figure 2 Mean \pm S.E. serum leptin concentrations, expressed as percent change from basal concentrations in all groups. Sampling was every other hour from 0800 to $1800 \mathrm{~h}$ on day 1 , and from $0800 \mathrm{~h}$ on day 2 to $1800 \mathrm{~h}$ on day 3. 
Diagnostics, Mannheim, Germany). Serum insulin and cortisol concentrations were determined by RIA with Pharmacia Insulin RIA (Pharmacia \& Upjohn, Uppsala, Sweden) and DSL Cortisol RIA (Diagnostic Systems Laboratories, Webster, TX, USA) respectively.

\section{Statistics}

Data are presented as means \pm S.E., and statistical significance was accepted at $P \leq 0.05$. Statistical analysis was done on absolute values, while in the figures the data are presented as percent change from baseline.

Statistical differences over time were calculated by ANOVA for repeated measurements with post-hoc testing using Tukey's test where appropriate. The variables were log transformed for the analysis when they were not normally distributed. Data were analysed with the program Statistica (Statsoft, Inc., Tulsa, OK, USA).

\section{Results}

Serum leptin increased significantly within $5 \mathrm{~h}$ following each meal $(P<0.01$, Fig. 2$)$. In the groups eating 12-hourly, leptin declined in the evening but rose again in response to the evening meal. The rise in leptin after the meal taken in the evening $(36 \mathrm{~h})$ was greater than after the same meal taken in the morning $(P<0.001$, Figs 2 and 3$)$. In those fasting for $48 \mathrm{~h}$, leptin decreased by $60 \%$ and showed no diurnal variation. Leptin rise was higher following $48 \mathrm{~h}$ of fasting when compared with the response on day 1 in the same individuals or the response to the same meal on day 3 in the groups eating 12-hourly $(P<0.02$, Fig. 3).

DEX increased leptin concentrations in those eating intermittently $(P<0.02$, Fig. 2$)$. The difference was statistically significant at $2000 \mathrm{~h}$ on day 2, i.e. after a total of $0.4 \mathrm{mg}$ DEX. Thereafter, the differences between the two groups were constant, i.e. no cumulative effect. There was no difference in leptin between those taking DEX and controls in the groups fasting for $48 \mathrm{~h}$.

Glucose and insulin increased significantly following each meal $(P<0.001$, Figs 4 and 5$)$. In the groups fasting for $48 \mathrm{~h}$, the rise in glucose and insulin in response to the meal taken on day 3 was significantly higher when compared with the response on day 1 $(P<0.001)$.

The diurnal rhythm for cortisol was maintained in all groups (Fig. 6). The groups taking DEX tended to have lower nadirs, but the difference was not statistically significant.

\section{Discussion}

We investigated the effect of different durations of fasting with and without a low dose of glucocorticoids on the leptin diurnal variation and response to a standard meal. In a previous study, we reported for the first time a 4-fold increase in serum leptin in response to energy intake, TPN, given after surgery in otherwise healthy patients (28). In addition, we also reported that leptin concentrations did not decrease in response to fasting in the control group that had only saline infusion for $24 \mathrm{~h}$ after the surgery (28). Our hypothesis

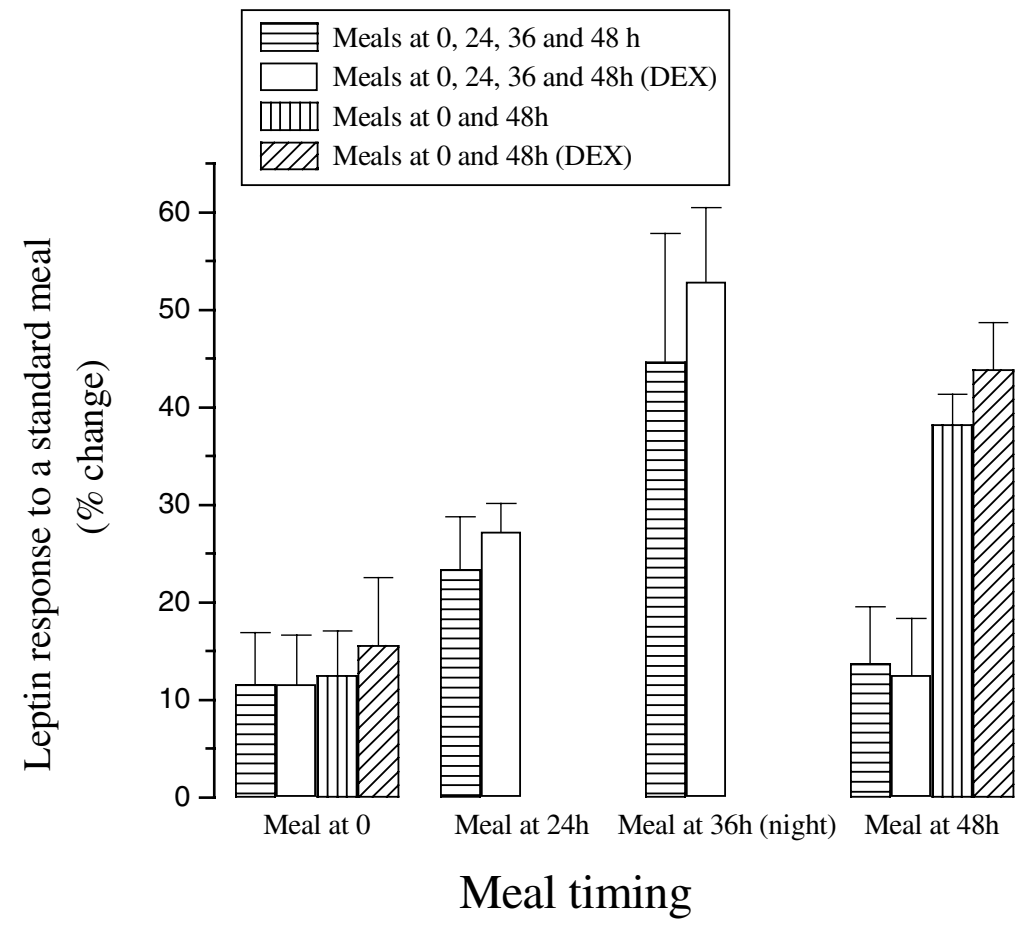

Figure 3 Mean \pm S.E. serum leptin response to a standard meal given at $0,24,36$ and $48 \mathrm{~h}$. The leptin response was calculated by subtracting individual leptin levels just before eating a standard meal from the levels $5 \mathrm{~h}$ after the meal.

www.eje.org 


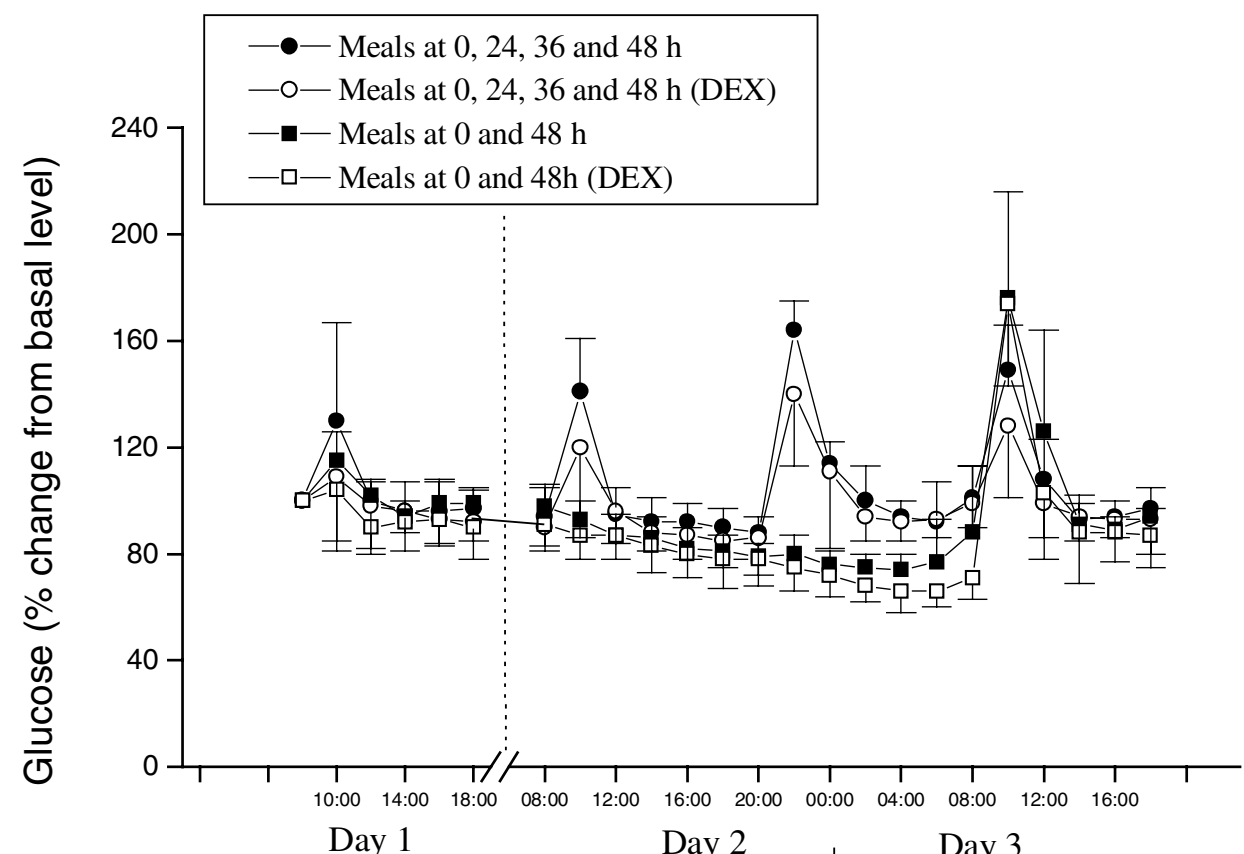

Time

Figure 4 Mean \pm S.E. serum glucose concentrations, expressed as percent change from basal concentrations, in all groups. Sampling was every other hour from 0800 to $1800 \mathrm{~h}$ on day 1 , and from $0800 \mathrm{~h}$ on day 2 to $1800 \mathrm{~h}$ on day 3.

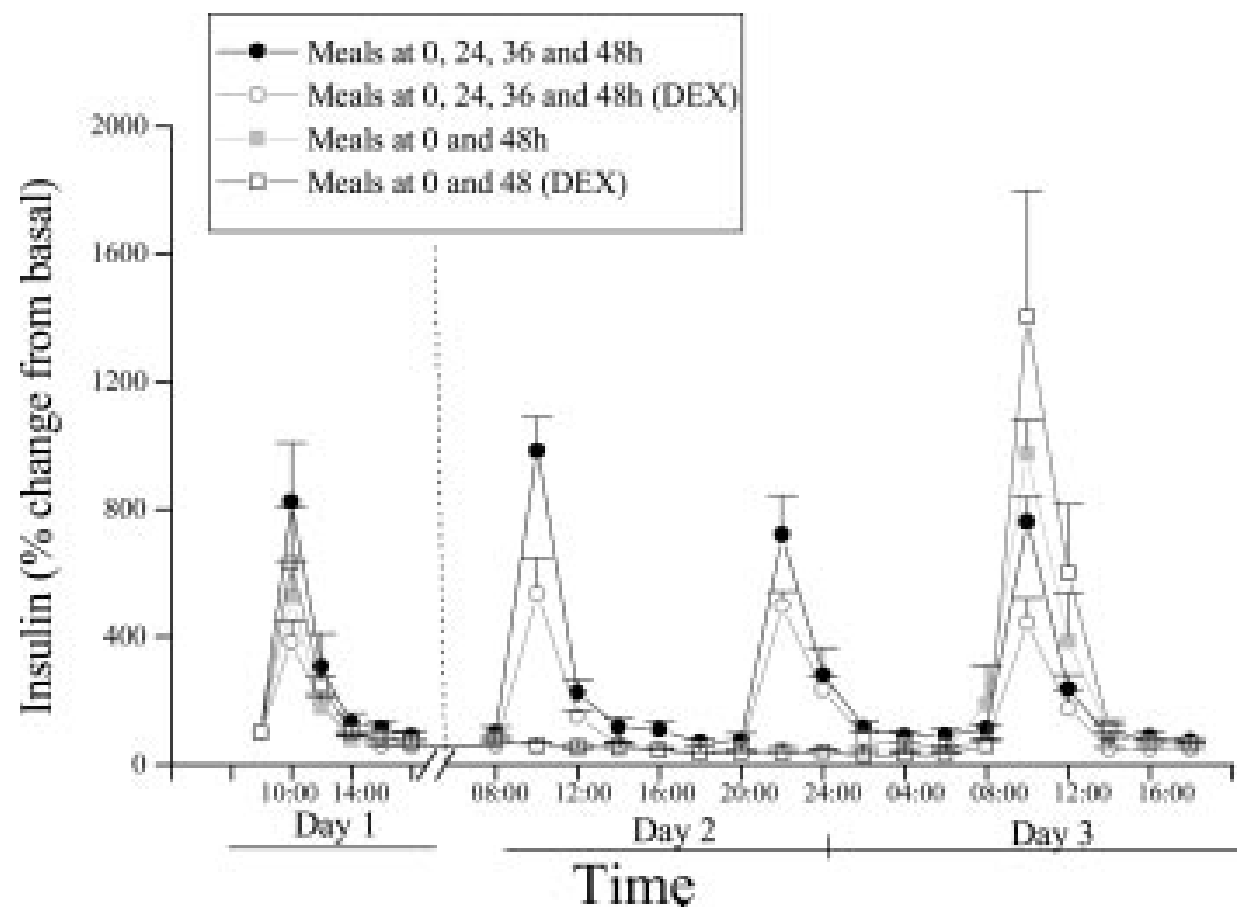

Figure 5 Mean \pm S.E. serum insulin concentrations, expressed as percent change from basal concentrations, in all groups. Sampling was every other hour from 0800 to $1800 \mathrm{~h}$ on day 1 , and from $0800 \mathrm{~h}$ on day 2 to $1800 \mathrm{~h}$ on day 3. 


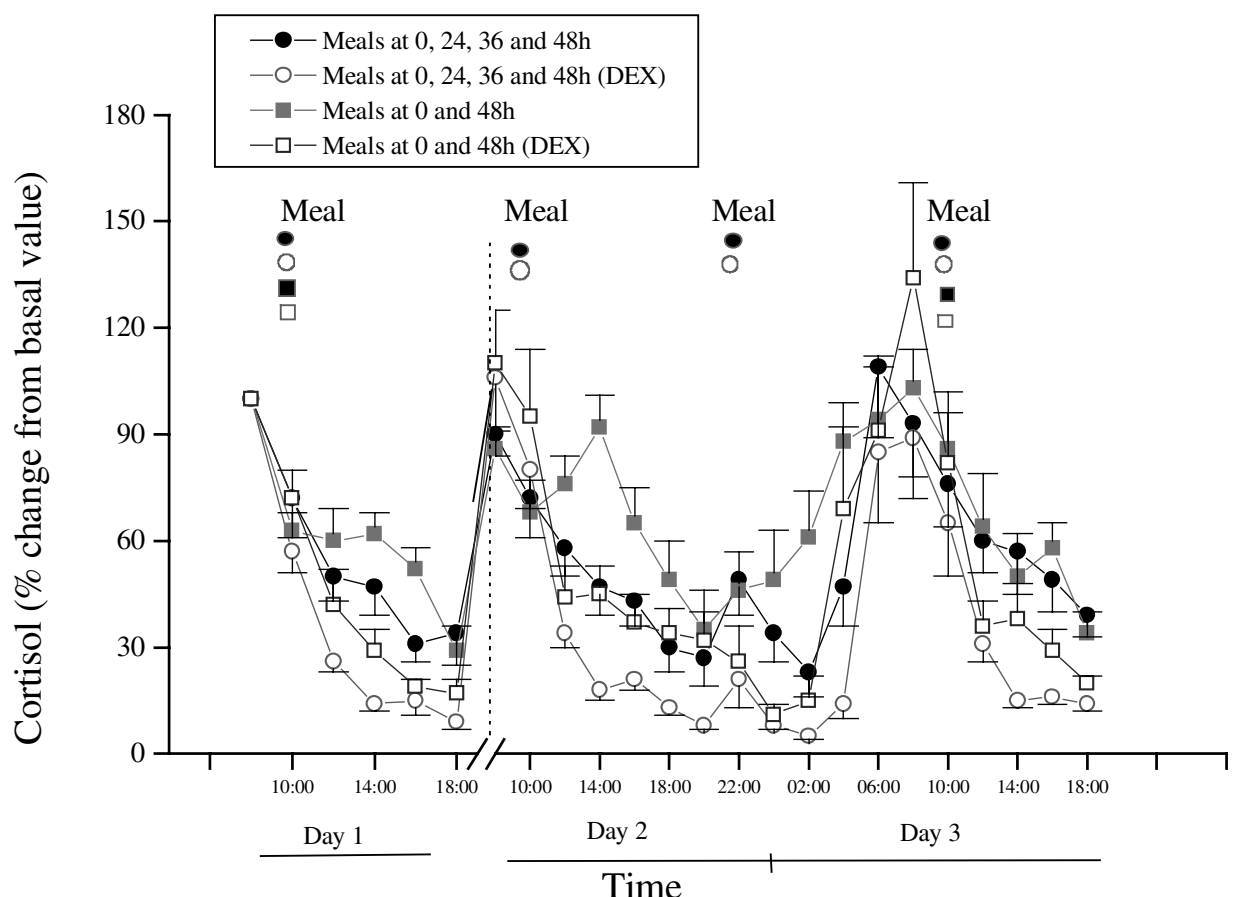

Figure 6 Mean \pm S.E. serum cortisol concentrations, expressed as percent change from basal concentrations, in all groups. Sampling was every other hour from 0800 to $1800 \mathrm{~h}$ on day 1 , and from $0800 \mathrm{~h}$ on day 2 to $1800 \mathrm{~h}$ on day 3 .

was that the perioperative fasting and stress contributed to this, possibly mediated by the observed increase in insulin and cortisol concentrations. In this study, fasting did sensitise the leptin response to food intake but the marked rise observed in the previous study could not be detected. The DEX dose was given to simulate the rise observed in cortisol in the previous study. Despite the higher leptin concentrations in those taking DEX and eating 12-hourly, DEX did not add to the rise in leptin induced by food intake, nor did it prevent the fall in leptin induced by fasting. Thus, the present data indicate that factors other than fasting and glucocorticoids are necessary for a marked postprandial leptin rise. Possible factors could be gut factors related to oral intake vs parenteral administration of calories, the increased interleukins and tumour necrosis factor alpha observed during the perioperative period (A Elimam \& C Marcus, unpublished observations) or the maintained rise in glucose and insulin induced by the TPN infusion (28). However, it is also possible that the DEX dose was too small if compared with the stress-induced rise in cortisol.

In most studies, exogenous glucocorticoids are reported to upregulate leptin $(11,13)$, but it has been questioned if the effect is limited to pharmacological dosing (31). The findings in this study support our previous report that glucocorticoids within the physiological range upregulate plasma leptin (13), as this was also noticed following the ingestion of a total of $0.4 \mathrm{mg}$ DEX in the volunteers eating twice a day. In contrast, DEX did not increase leptin in those fasting for $48 \mathrm{~h}$ when compared with the control group. Thus, glucose and/or insulin are required for the glucocorticoid effect on leptin. In vitro studies reported that cortisol potentiated the insulin-induced upregulation of leptin in adipocytes (32). In one study, administration of $4 \mathrm{mg}$ DEX i.v. to healthy volunteers increased serum leptin in fed subjects and not in those fasting when measured over $10 \mathrm{~h}$ (33). In addition, the same group reported that under prolonged fasting conditions, $24 \mathrm{~h}$, DEX did not increase daytime leptin concentrations but increased leptin during the night (34). We have not observed this, as leptin concentrations were not different from controls in those taking DEX and fasting for $48 \mathrm{~h}$. This could be explained by our choice of a low dose within the physiological range, while in both previous reports high doses of DEX were used, 4 and $2 \mathrm{mg}$ respectively. In addition, in these studies a short washout time between the experiments was used, 1-4 weeks. We have previously reported that the hypothalamic-pituitaryadrenal axis is affected for a long time after exposure to low doses of glucocorticoids (29).

The regulation of the leptin diurnal profile is still unclear. When first reported, no relationship to acute changes following food intake could be shown and it was claimed to be negatively correlated to the pituitary-adrenal activity $(20,24)$. However, patients with panhypopituitarism, resulting from perinatal stalk transection syndrome or resection of pituitary 
tumours, retain a normal diurnal rhythm $(35,36)$. An intact hypothalamic-pituitary axis is therefore not essential for the regulation of leptin circadian rhythm. Other groups reported that the diurnal rhythm of leptin is entrained to meal timing and not to the circadian clock $(21,37)$. Our results show that the pattern of food intake affects the diurnal rhythm but does not agree with a complete lack of effect of the circadian clock, as leptin response to the evening meal was higher. Therefore, a still unrevealed factor also contributes to the leptin rhythm. In agreement with this is the persistence of the diurnal pattern during continuous enteral nutrition (38). However, the difference in the leptin response could also be explained by the higher glucose and insulin responses in the evening, which were in agreement with a previous report (39).

The volunteers eating 12-hourly had declining leptin concentrations before the evening meal, and the leptin diurnal profile was different from that previously reported in healthy humans eating three meals a day $(21,37)$. This suggests that the reported typical leptin pattern, with leptin rising during the evening and night, is due to the cumulative effect of the food taken during the day.

In conclusion, fasting sensitised the leptin response to food intake but our hypothesis that the post-surgery energy-induced leptin rise is due to fasting and an increased serum glucocorticoid concentration was not proved in this study. The effect of exogenous glucocorticoids on leptin concentrations is blunted in subjects who are fasting for long durations. Feeding has a permissive effect on the leptin diurnal rhythm, but it is not the only decisive factor, since postprandial leptin increase during the night is more pronounced than during the daytime.

\section{Acknowledgements}

The authors thank Åsa Walldén for helping with the meal choice. This study was supported by grants from the Wera Ekström Foundation, the Frimurare Barnhuset Foundation, the Jerring Foundation, the Samariten Foundation, the Swedish Society for Medical Research, and the Swedish Medical Research Council (9941).

\section{References}

1 Rohner-Jeanrenaud F \& Jeanrenaud B. Obesity, leptin, and the brain. New England Journal of Medicine 1996334 324-325.

2 Montague CT, Farooqi IS, Whitehead JP, Soos MA, Rau H, Wareham NJ et al. Congenital leptin deficiency is associated with severe early-onset obesity in humans. Nature $1997 \mathbf{3 8 7}$ 903-908.

3 Clément K, Vaisse C, Lahlou N, Cabrol S, Pelloux V, Cassuto D et al. A mutation in the human leptin receptor gene causes obesity and pituitary dysfunction. Nature $1998392398-401$.
4 Zhang Y, Proenca R, Maffei M, Barone M, Leopold L \& Friedman JM. Positional cloning of the mouse obese gene and its human homologue. Nature 1994372 425-432.

5 Hassink SG, Sheslow DV, de Lancey E, Opentanova I, Considine RV \& Caro JF. Serum leptin in children with obesity: relationship to gender and development. Pediatrics 199698 201-203.

6 Klein S, Coppack SW, Mohamed-Ali V \& Landt M. Adipose tissue leptin production and plasma leptin kinetics in humans. Diabetes $199645984-987$.

7 Maffei M, Halaas J, Ravussin E, Pratley RE, Lee GH, Zhang Y et al. Leptin levels in human and rodent: measurement of plasma leptin and ob RNA in obese and weight-reduced subjects. Nature Medicine 19951 1155-1161.

8 Himms-Hagen J. Physiological roles of the leptin endocrine system: differences between mice and humans. Critical Reviews in Clinical Laboratory Sciences 199936 575-655.

9 Mantzoros CS. The role of leptin in human obesity and disease: a review of current evidence. Annals of Internal Medicine 1999130 $671-680$.

10 Fried S, Ricci M, Russel C \& Laferrere B. Regulation of leptin production in humans. Journal of Nutrition $2000 \mathbf{1 3 0}$ 3127S-3131S.

11 Larsson H \& Ahren B. Short-term dexamethasone treatment increases plasma leptin independently of changes in insulin sensitivity in healthy women. Journal of Clinical Endocrinology and Metabolism $1996 \mathbf{8 1} 4428-4432$.

12 Miell JP, Englaro P \& Blum WF. Dexamethasone induces an acute and sustained rise in circulating leptin levels in normal human subjects. Hormone and Metabolic Research 199628 704-707.

13 Elimam A, Knutsson U, Brönnegård M, Stierna P, AlbertssonWikland K \& Marcus C. Variation in glucocorticoids within the physiological range affect plasma leptin levels. European Journal of Endocrinology $1998139615-620$.

14 Malmstrom R, Taskinen MR, Karonen SL \& Yki-Jarvinen H. Insulin increases plasma leptin concentrations in normal subjects and patients with NIDDM. Diabetologia 199639 993-996.

15 Utriainen T, Malmstrom R, Makimattila S \& Yki-Jarvinen H. Supraphysiological hyperinsulinemia increases plasma leptin concentrations after $4 \mathrm{~h}$ in normal subjects. Diabetes $1996 \mathbf{4 5}$ $1364-1366$.

16 Saad MF, Khan A, Sharma A, Michael R, Riad-Gabriel MG, Boyadjian $\mathrm{R}$ et al. Physiological insulinemia acutely modulates plasma leptin. Diabetes $1998 \mathbf{4 7} 544-549$.

17 Kolaczynski JW, Nyce MR, Considine RV, Boden G, Nolan JJ, Henry $\mathrm{R}$ et al. Acute and chronic effects of insulin on leptin production in humans: studies in vivo and in vitro. Diabetes 1996 45 699-701.

18 Boden G, Chen X, Kolaczynski JW \& Polansky M. Effects of prolonged hyperinsulinemia on serum leptin in normal human subjects. Journal of Clinical Investigation 1997100 1107-1113.

19 Tuominen JA, Ebeling P, Stenman UH, Heiman ML, Stephens TW \& Koivisto VA. Leptin synthesis is resistant to acute effects of insulin in insulin-dependent diabetes mellitus patients. Journal of Clinical Endocrinology and Metabolism 199782 381-382.

20 Sinha MK, Ohannesian JP, Heiman ML, Kriauciunas A, Stephens TW, Magosin S et al. Nocturnal rise of leptin in lean, obese, and non-insulin-dependent diabetes mellitus subjects. Journal of Clinical Investigation 199697 1344-1347.

21 Schoeller DA, Cella LK, Sinha MK \& Caro JF. Entrainment of the diurnal rhythm of plasma leptin to meal timing. Journal of Clinical Investigation $19971001882-1887$.

22 Taylor AE, Hubbard J \& Anderson EJ. Impact of binge eating on metabolic and leptin dynamics in normal young women. Journal of Clinical Endocrinology and Metabolism $1999 \mathbf{8 4}$ $428-434$.

23 Levy JR, LeGall-Salmon E, Santos M, Pandak WM \& Stevens W. Effect of enteral versus parenteral nutrition on leptin gene expression and release into the circulation. Biochemical and Biophysical Research Communications 1997237 98-102.

24 Korbonits M, Trainer PJ, Little JA, Edwards R, Kopelman PG, Besser GM et al. Leptin levels do not change acutely with food 
administration in normal or obese subjects, but are negatively correlated with pituitary-adrenal activity. Clinical Endocrinology $199746751-757$.

25 Weigle DS, Duell PB, Connor WE, Steiner RA, Soules MR \& Kuijper JL. Effect of fasting, refeeding, and dietary fat restriction on plasma leptin levels. Journal of Clinical Endocrinology and Metabolism 199782 561-565.

26 Kolaczynski JW, Considine RV, Ohannesian J, Marco C, Opentanova I, Nyce MR et al. Responses of leptin to short-term fasting and refeeding in humans: a link with ketogenesis but not ketones themselves. Diabetes 199645 1511-1515.

27 Grinspoon SK, Askari H, Landt ML, Nathan DM, Schoenfeld DA, Hayden DL et al. Effects of fasting and glucose infusion on basal and overnight leptin concentrations in normalweight women. American Journal of Clinical Nutrition 1997 $661352-1356$.

28 Elimam A, Tjäder I, Norgren S, Wernerman J, Essen P, Ljungqvist $\mathrm{O}$ et al. Total parenteral nutrition after surgery rapidly increases serum leptin levels. European Journal of Endocrinology 2001144 $123-128$.

29 Knutsson U, Stierna P, Marcus C, Carlstedt-Duke J, Carlstrom K \& Bronnegard M. Effects of intranasal glucocorticoids on endogenous glucocorticoid peripheral and central function. Journal of Endocrinology 1995144 301-310.

30 Thorner M, Vance M, Horvath E \& Kovacs K. The anterior pituitary. In Williams' Text Book of Endocrinology, edn 8, ch 6, pp 221-310. Eds J Wilson \& D Foster. Philadelphia, PA: WB Saunders Company, 1992.

31 Torpy DJ, Bornstein SR, Cizza G \& Chrousos GP. The effects of glucocorticoids on leptin levels in humans may be restricted to acute pharmacologic dosing. Journal of Clinical Endocrinology and Metabolism 199883 1821-1822.

32 Wabitsch M, Jensen PB, Blum WF, Christoffersen CT, Englaro P, Heinze E et al. Insulin and cortisol promote leptin production in cultured human fat cells. Diabetes 199645 1435-1438.
33 Laferrére B, Fried SK, Hough K, Campbell SA, Thornton J \& Pi-Sunyer FX. Synergistic effects of feeding and dexamethasone on serum leptin levels. Journal of Clinical Endocrinology and Metabolism $1998 \mathbf{8 3} 3742-3745$.

34 Laferrére B, Fried SK, Osborne T \& Pi-Sunyer FX. Effect of one morning meal and a bolus of dexamethasone on 24-hour variation of serum leptin levels in humans. Obesity Research 20008 481-486.

35 Pombo M, Pombo CM, Astorga R, Cordido F, Popovic V, GarciaMayor RV et al. Regulation of growth hormone secretion by signals produced by the adipose tissue. Journal of Endocrinological Investigation 199922 22-26.

36 Kousta E, Chrisoulidou A, Lawrence NJ, al-Shoumer KA, Parker $\mathrm{KH}$, McCarthy MI et al. The circadian rhythm of leptin is preserved in growth hormone deficient hypopituitary adults. Clinical Endocrinology $1998 \mathbf{4 8} 685-690$.

37 Dallongeville J, Hecquet B, Lebel P, Edme JL, Le Fur C, Fruchart JC et al. Short term response of circulating leptin to feeding and fasting in man: influence of circadian cycle. International Journal of Obesity and Related Metabolic Disorders 199822 728-733.

38 Simon C, Gronfier C, Schlienger JL \& Brandenberger G. Circadian and ultradian variations of leptin in normal man under continuous enteral nutrition: relationship to sleep and body temperature. Journal of Clinical Endocrinology and Metabolism $1998 \quad \mathbf{8 3}$ 1893-1899.

39 Plat L, Leproult R, Lhermite-Baleriaux M, Fery F, Mockel J, Polonsky KS et al. Metabolic effects of short-term elevations of plasma cortisol are more pronounced in the evening than in the morning. Journal of Clinical Endocrinology and Metabolism $1999843082-3092$.

Received 13 December 2001

Accepted 26 April 2002 